\title{
Endomycorrhizae in Miocene paleosols: Implications in biotite weathering and accumulation of dolomite in plant roots (SW Madrid Basin, Spain)
}

\author{
M.E. Sanz-Montero *, J.P. Rodríguez-Aranda \\ Dpto. de Petrología y Geoquímica, Fac. de Ciencias Geológicas, UCM, C/ José Antonio Novais, 2. 28040, Madrid, Spain
}

a b s t r a c t

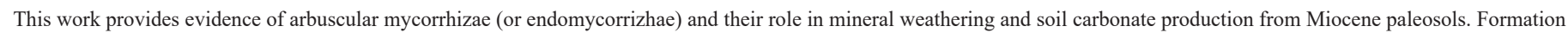

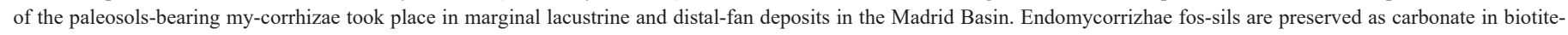

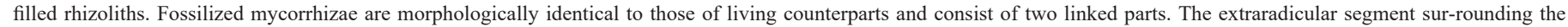

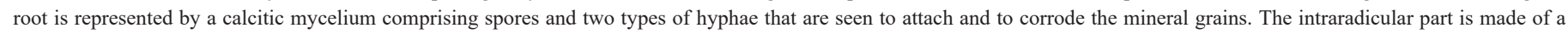

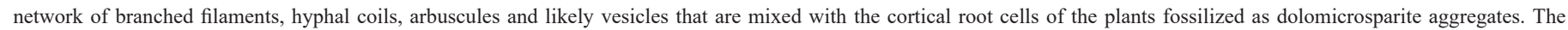

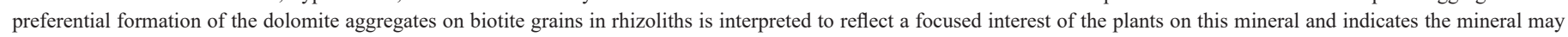

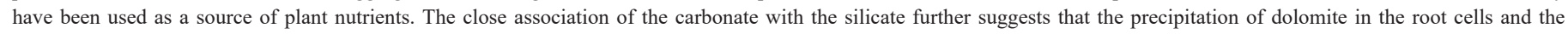

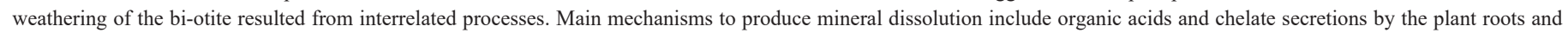
fungi which would remove nutrients.

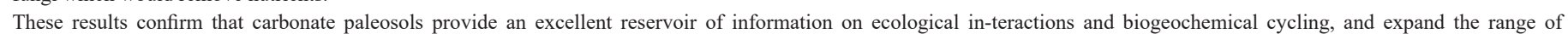

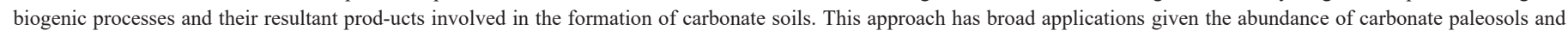
the endomycorrhiza record dating back 400 million years.

Keywords: Bioweathering, Biomineralization, Mutualistic association, Silicate, Carbonate soils Fungi

\section{Introduction}

In a small volume of soil surrounding roots exits a mutualistic rela-tionship between the plant roots and a complex microbial community that is called rhizosphere (Hinsinger et al., 2006). The rhizosphere asso-ciation is involved in the formation and destruction of minerals in soils (Uroz et al., 2009). Such that, plant-influenced chemical weathering of silicates might have caused accelerated terrestrial carbonate production from Devonian onwards (Brasier, 2011). For example, weathering of magnesium silicates produces free $\mathrm{Ca}$ and $\mathrm{Mg}$ that linked to bicarbonate ions can result in the precipitation of dolomite. Carbonate precipitation and silicate weathering strongly impact global carbon cycling (Berner, 1992; Manning, 2008). In addition, silicate weathering plays a funda-mental role in the environment by influencing the bioavailability of chemical elements such as $\mathrm{K}, \mathrm{Mg}, \mathrm{Ca}$ and $\mathrm{Fe}$ that can be crucial for plant nutrition in nutrient-poor soils (Calvaruso et al., 2006). Both lab-oratory and field studies provide evidence that mycorrhizal fungi are able to solubilize silicate and carbonate minerals to promote plant

\footnotetext{
* Corresponding author.

E-mail address: mesanz@geo.ucm.es (M.E. Sanz-Montero).
}

growth and precipitated oxalate crystals in the hyphae (Glowa et al., 2003; Kolo and Claeys, 2005). Biotite is a phyllosilicate which is fre-quently present in soil, and holds $\mathrm{K}, \mathrm{Mg}$, and $\mathrm{Fe}$ nutrients and thus weathers more intensively in the rhizosphere than in the bulk soil (April and Keller, 1990; Stucki et al., 1996; Calvaruso et al., 2006; Christophe et al., 2006; Uroz et al., 2009; Balogh-Brunstad et al., 2008). Main mechanisms to produce mineral dissolution include organ-ic acids and chelate secretions by the plant roots and their symbiotic or-ganisms (Calvaruso et al., 2006; Uroz et al., 2009).

The accumulation of carbonate in root-cells to produce Microco-dium structures is a feature of carbonate paleosols that, according to Klappa (1978), results from the calcification of mycorrhizae, a symbi-otic association between fungi and the cortical cells of the roots. The calcification of the root cortical cells is favoured by the charged poly-saccharide components of the roots (Alonso-Zarza et al., 1998). Alter-natively, the precipitation of carbonate has been suggested to be an effective nutrient-acquiring mechanism used by certain plants inha-biting nutrient-poor carbonate substrates through proton secretion of rhizosphere that does not require the participation of mycorrizhae (Kosir, 2004).

The presence of mycorrhizal fungi in the rock record has been hardly ever documented and even less its involvement in mineral 
dissolution. In this paper, we report evidence of endomycorrhizae fungi and their role in biotite weathering and dolomite accumulation in root structures (rhizoliths) preserved in Miocene paleosols of the Madrid Basin. Biotite weathering was likely promoted by the mycor-rhizae as a strategy to acquire nutrients by increasing solubility of soil minerals. Bioweathering provided the ions required to dolomite pre-cipitation in the colonized root cells. This work expands the range of biogenic processes and their resultant products involved in the for-mation of carbonate soils.

\section{Geological setting}

The studied paleosols crop out in the southern part of the Madrid Basin This is a Tertiary basin, located in the central area of the Iberian Peninsula (Fig. 1). The formation and tectono-sedimentary evolution of this continental basin is related to the relative movements during the alpine orogeny among the African and the Euroasian lithospheric plates, and the Iberian and Alboran microplates (Calvo et al., 1996). The basin is locked between the Central System in the northwest (main-ly composed of granites and metamorphic rocks), the Mesozoic Iberian and Altomira Ranges in the East (mainly dolostone and limestone rocks), and the Toledo Mountains in the south (mainly granitic rocks)(Fig. 1). The up to $2000 \mathrm{~m}$ thick Miocene stratigraphical record of the Madrid Basin is divided into three main flat-lying lithostratigraphic units, each separated by unconformities from their underlying units (Calvo et al., 1996). In many cases these unconformities are defined by paleokarstic surfaces (Rodríguez-Aranda et al., 2002). The studied succession is located in the basal part of the Intermediate Unit (Middle
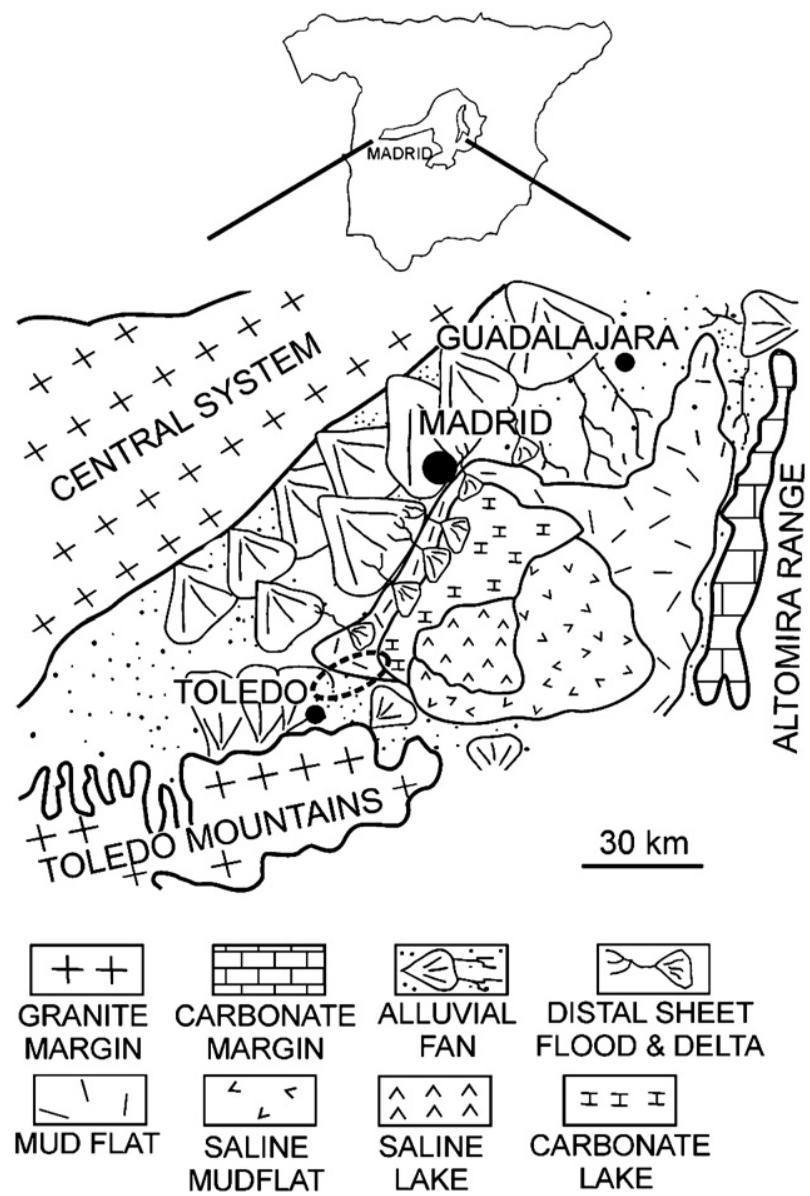

Fig. 1. Paleogeographic sketch of the Madrid Basin with location of the study area (encircled) at the time when the lower part of the Intermediate Miocene Unit was deposited.
Aragonian continental stage, approximately 16 My ago). The general sedimentary context for this unit is established as an alluvial fan - lake complex characteristic of a hydrologically-closed basin (Fig. 1). The alluvial fan deposits extend up to $20 \mathrm{~km}$ northward from the basin margin. The catchment area is mainly located in Paleozoic granitic areas of the Toledo Mountains.

\section{Methods}

The basal part of the Miocene Intermediate Unit has been studied in an area of approximately $100 \mathrm{~km}^{2}$ in the SW part of the Madrid Basin. The carbonate paleosols were logged and sampled in well-exposed outcrops in the vicinity of the Bargas village (Toledo; Fig. 1). The mineralogy of the samples was determined by X-ray diffraction (XRD) of powdered samples on a Philips $\mathrm{X}$-ray diffraction system. Op-tical and fluorescence examinations of standard thin-sections stained for carbonates (Alizarin Red-S and potassium ferricyanide) were per-formed using an Olympus BX51 microscope with a white light source and a green-ultraviolet filter, respectively. In addition, thin sections were studied using a high magnification microscope, Nikon-DS-Fil, equipped with $\times 60$ and $\times 100$ oil- immersion objectives. For high-resolution textural analysis, carbon-coated thin sections and fresh broken surfaces of previously air-dried and gold-coated samples were studied with scanning electron microscopy provided with X-ray energy-dispersive spectroscopy, SEM-EDS (JEOL JSM-840). Both secondary electron (SE) and backscattered electron (BSE) images were collected. The stoichiometry of ten individual dolomite crystals was established by electron microprobe spot analyses using a JEOL Superprobe JXA 8900-M.

\section{Sedimentary succession and paleoenvironment}

Deposits representative of the basal part of the Miocene Interme-diate Unit in the study area were formed in sandflat and mudflat sub-environments fringing a central carbonate lake (Fig. 1). Sandflat deposits are found SW of the study zone and consist mainly of poorly indurated arkosic sandstone that represent sheet flood and stream channel deposits from the alluvial fan. In the northeast the mudflat-lake subenvironments are composed of fine-grained sandstone and siltstone interbedded with red and green mudstone, whitish dolo-marlstone, and dolostone beds. The transition between the arkosic alluvial fans and the lake environment takes place in a narrow belt near the locality of Bargas. In this transitional area is found the paleosol-bearing succession which is the focus of this study (Fig. 2). It is up-to- $14 \mathrm{~m}$ thick and continuous laterally for 20 to $500 \mathrm{~m}$. For descrip-tive purposes, the succession has been divided in three main parts.

The lower part $(5 \mathrm{~m})$ consists of ochre-coloured arkosic sandstone and siltstone facies cemented by dolomicrite that grade upwards to siliciclastic mudstones (Figs. 2 and 3). The detrital grains are quartz, feldspars and micas (chiefly biotite). Illite is the major component of the clay fraction. Siltstone facies show stacked multi-horizon dolo-mite profiles (Fig. 3A). Each profile contains a massive micritic hori-zon with abundant $\mathrm{cm}$-sized dolomite rhizoliths and nodules capped by a discontinuous and indurated horizon formed by the coa-lescence of dolomite rhizoliths and nodules (Fig. 3B). The upper paleosol is overlaid by red and green mudstones with root bioturba-tion. Mudstone facies grade upwards to the middle part of the succes-sion (Fig. 3C). This part is $2.5 \mathrm{~m}$ thick and is composed by vaguely laminated dolostone, brecciated dolostone and arkosic sandstone beds. Dolostones occur interbedded with thin $(1 \mathrm{~mm}-1 \mathrm{~cm})$ green mudstone and siltstone. Dolostone beds show a crude lamination that is disrupted by closely-packed pedotubules that extend both ver-tically and horizontally up to several centimetres and can be filled by detrital grains and dolomite cements (Fig. 3C). These beds grade into a brecciated dolostone that, in turn, is overlied by massive arkosic sandstone cemented by dolomite. The base of the sandstone is 


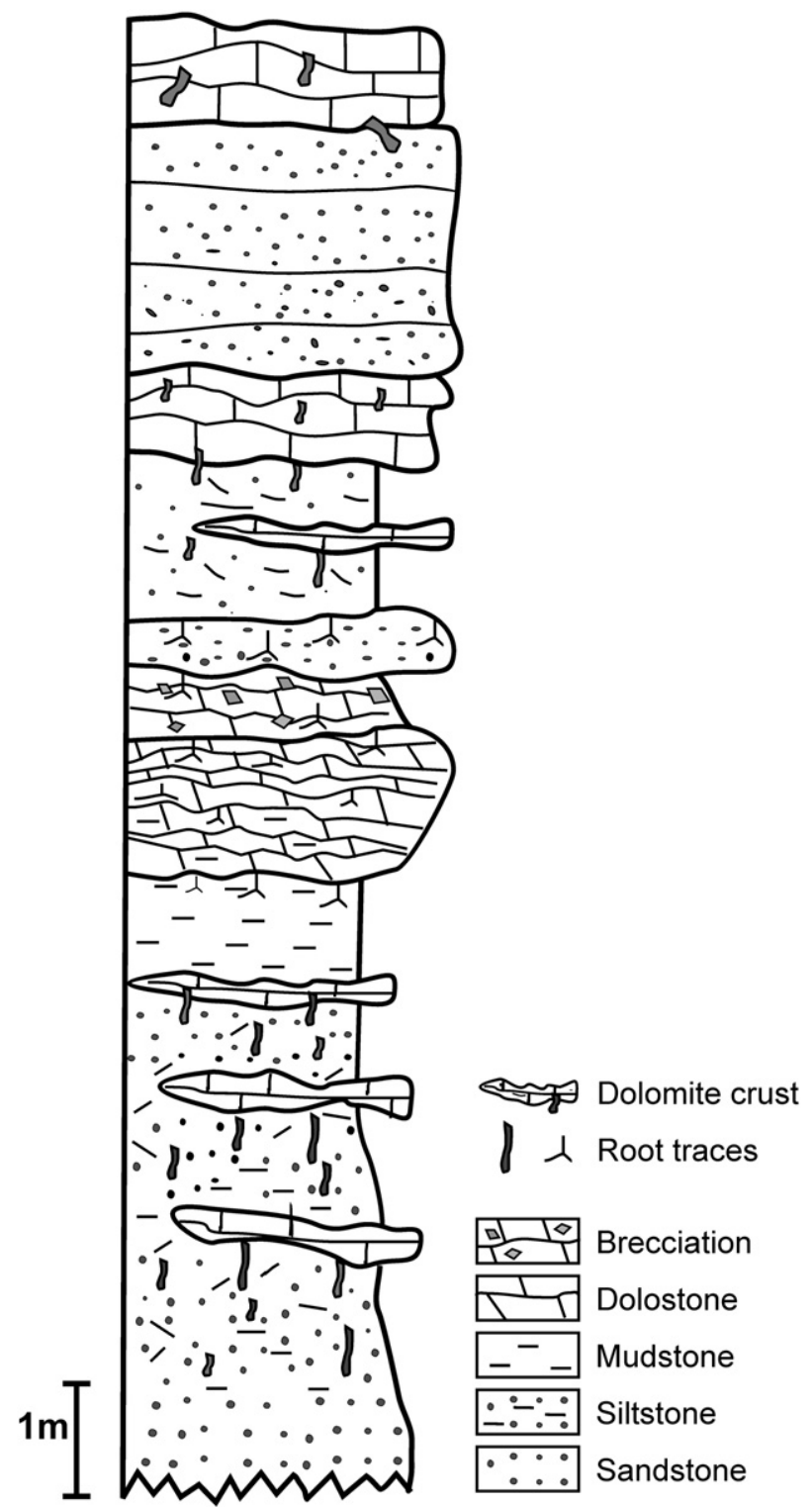

Fig. 2. Log of the sedimentary succession showing carbonate paleosols developed in al-luvial and lacustrine facies deposits.

defined by a distinct erosion surface (Fig. 3D). Above this, the upper interval of the sedimentary section $(6 \mathrm{~m})$ comprises a succession of siltstone exhibiting distinct dolocrete profiles, cross-bedded sand-stone and continuous indurated dolocrete crusts.

The vertical succession of facies reflects a gradual expansion of lake facies (dolostone) over mudflat deposits (mudstone-siltstone) followed by a progradation of the alluvial systems (siltstone-sandstones) into the lacustrine areas (Figs. 1 and 2).

The abundance of organosedimentary structures (rhizoliths or root casts) within the studied facies suggests that they are best inter-preted as cyclic pedogenic dolocrete formed by precipitation of car-bonate in the vadose zone (Wright and Tucker, 1991; Sanz-Montero and Wright, 1994; Alonso-Zarza, 2003; Alonso-Zarza and Wright, 2010). The occurrence of successive dolocrete profiles within the studied host sediment indicates that dolocretization was cyclic, i.e., an episode of sedimentation followed by a period of stagnation dur-ing which a soil profile was developed. This was attributed to alterna-tion of periods of uplift and stability of the basin margins and favoured the generalized formation of dolocretes in the southern part of the Madrid Basin (Sanz et al., 1994).
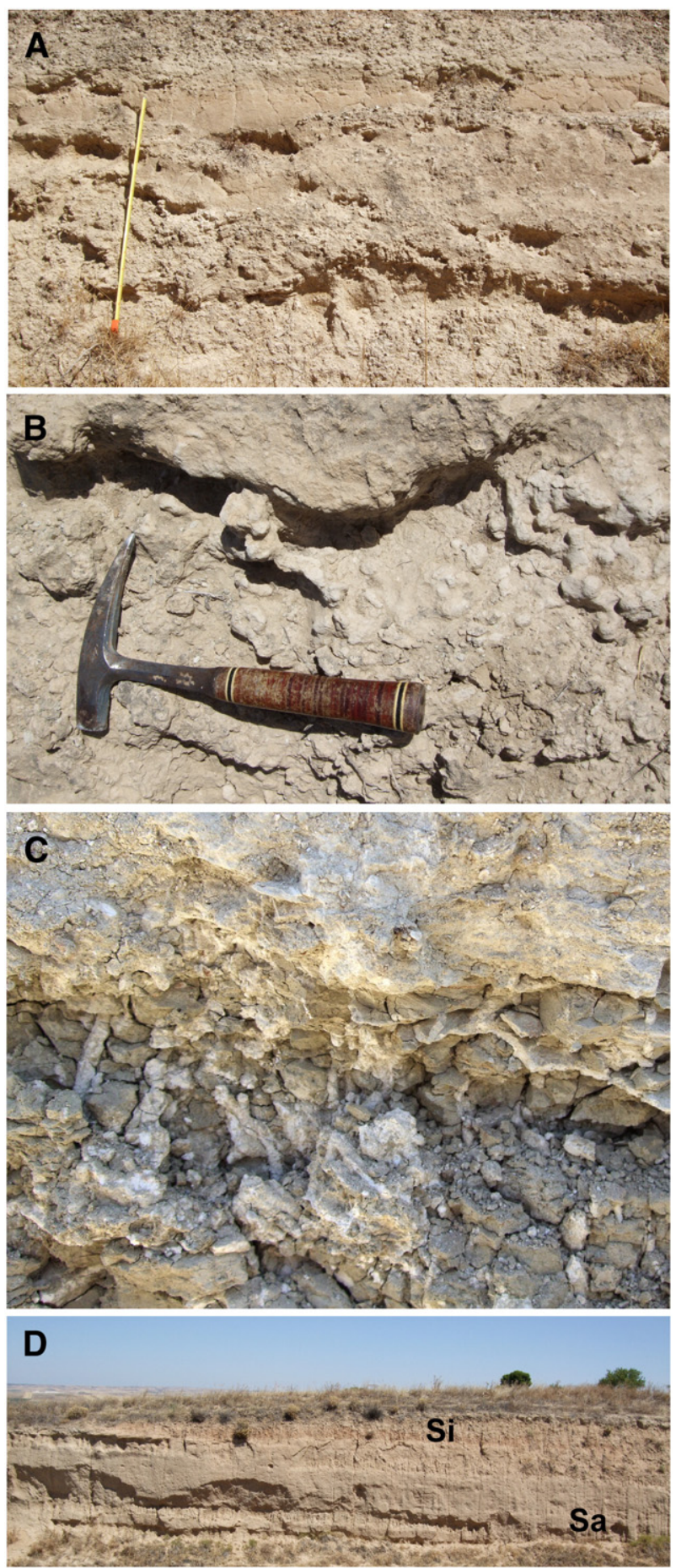

Fig. 3. Outcrop images of the paleosol-bearing succession in the study area. A) Distinct dolomitic soil profiles developed in siltstone. Scale $2 \mathrm{~m}$. B) Close view of amalgamated carbonate nodules and rhizoliths in dolocretes. C) Siliciclastic mudstone and dolostone with dolomitic rhizoliths. The width of the photo is $5 \mathrm{~cm}$. D) The upper part of the suc-cession consists of sandstone with erosive base $(\mathrm{Sa})$ and siltstone beds $(\mathrm{Si})$ capped by indurated dolocrete crusts.

Carbonatic horizons develop in soils where there is a net moisture deficit, such that carbonate produced in a drier season is not leached away during a wetter season (Wright, 2007). Most present-day carbo-natic soils form in areas with warm to hot climates and low, seasonal rainfall (Goudie, 1983). Based on mammal assemblages, Calvo et al.(1993) suggested semi-arid conditions for the Madrid Basin during the Middle Aragonian, which may had led to the formation of carbonatic soils in the study area. 


\section{Microscopic features}

Dolomite crystals associated to the exfoliated planes of biotite grains are found throughout the succession, but exclusively concentrated in root tubes irrespectively of the host strata (dolostone, siltstone, or sand-stone). In dolostone substrates, the root infill of biotite comes from the overlying siltstone deposits. In the detrital facies, biotite grains sur-rounding the root structures randomly float in the dolomicrite ground-mass and commonly show signs of oxidation but are not exfoliated. The typical ochre colour of the dolocretes is likely due to the oxidation of the ion included in these silicates.

Detailed microscopic observations have been carried out mostly in the rhizoliths containing biotites (Fig. 4). According to Klappa (1980), root structures have been identified at the microscopic scale, by size, morphology and structure. In transverse view, root traces display a gross circular morphology, mostly $100 \mu \mathrm{m}$ to $2 \mathrm{~mm}$ in diameter (Fig. 4A). In Iongitudinal sections, the morphology is tubular or cylin-drical (Fig. 4B). The traces are oriented vertically but oblique and hor-izontal distributions are also seen. The internal structure is irregularly preserved. It commonly consists of a mixture of dolomite crystals ag-gregates, silt-sized detrital grains, including quartz, feldspars, biotite, and minor muscovite, host fragments, organic remains and a variable volume of pores (Figs. 4C, D and 5). Lignified rests attributed to the outermost part of the roots (epidermis) have been scarcely observed (Fig. 4C). The rests consist of two symmetrically arranged segments separated by carbonate crystalline clusters. Thin, regularly distributed protrusions extend around $50 \mu \mathrm{m}$ outwards from the surface of the epidermis (Fig. 4C). The silicate grains inside the tubes show signs of corrosion. Specifically, biotite grains, unlike what happens with the grains that are outside the rhizoliths, are opened along the cleav-age planes and appear exfoliated (Figs. 4-6). In addition, most of the mica grains are broken with carbonate precipitated between them (Fig. 6). As seen through thin section examinations, openly to tightly-packed carbonate form crystalline aggregates between or around the biotite lamellae. The carbonate consists of dolomite (Fig. 7). According to the $\mathrm{Mg} / \mathrm{Ca}$ ratios determined in dolomite crystals (ranging from 0.96 to 1.02 ), these can be characterized as stoichiometric.

Carbonate aggregates display a gross polygonal cellular pattern (Figs. 4D, 5,6 and 8 ) and are made of a mixture of micrite and microsparite-sized crystals (1-30 $\mu \mathrm{m})$. Dolomite crystals commonly have cloudy (inclusion-rich) cores and/or porosity and relatively clear outer rims. Inner inclusions adopt variable morphologies including cir-cular, rhombic and, chiefly, filamentous (Fig. 5A). In more detail, the do-lomite crystals are outlined by a network of dichotomously branching filaments that laterally bifurcate forming tree-like structures of thin fil-aments (Fig. 5B,C). In some cases, this development culminates in a highly branched arbuscule inside the crystals.

It is notorious that dolomite crystals are plentiful in the vicinity of the biotite clasts and are much larger when they are next to them, whereas etching in other neighbouring silicates is not significantly coupled with the precipitation of dolomicrosparite (Fig. 6). The de-gree of breakage of the phyllosilicate is variable. In some cases the bi-otite grains are widely opened according to the polygonal arrangement of the dolomite precipitates inside, but their fragments remain linked (Fig. 6B). The dolomite crystals between the biotite laminae contain dichotomously branched filament-like structures, some of which are heavily branched (Fig. 6B). Other biotite grains are extensively exploited and their broken extremes occur scattered around (Fig. 6C and D). Then, laminar or sheet-like layers of dolomi-crosparite arrange along the exfoliated phyllosilicates with the crys-tals evenly distributed and oriented perpendicularly. The faces of the dolomite crystals in contact with the surface of the biotite are straight whereas the opposite faces display abundant embayments (Fig. 6C, D).

Multilayered patterns of isodiametric aggregates of dolomite sur-rounding detrital grains are also found in the rhizolith structures (Fig. 8). These rarely adopt vaguely concentric organizations. Porous subidiomorph crystals of dolomite with concave and convex surfaces represent the major component of the aggregates (Fig. 8B). These components are mixed with filament-like crystals and coil cluster-like crystals and linked together by a net of carbonaceous to poorly-
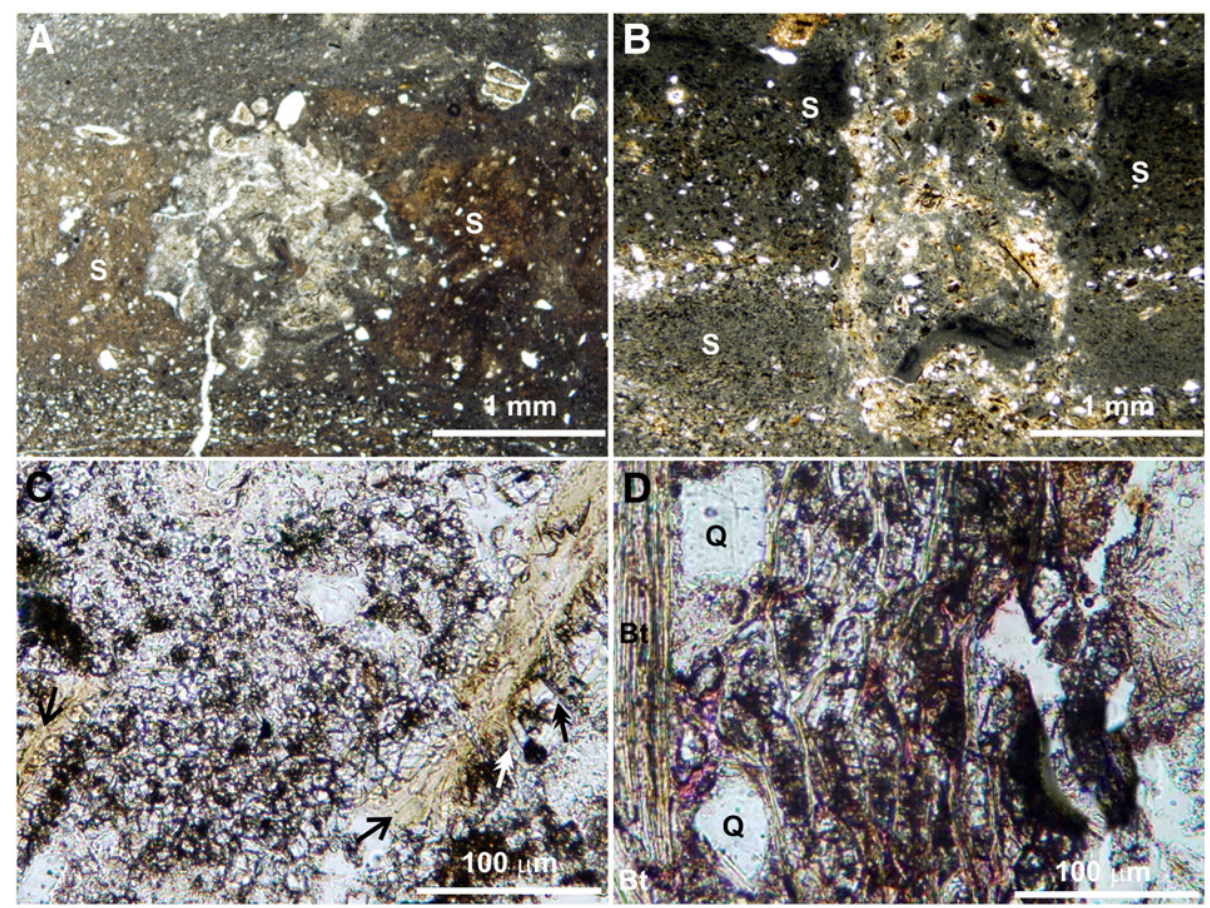

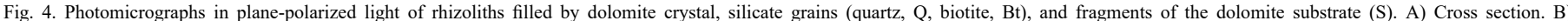

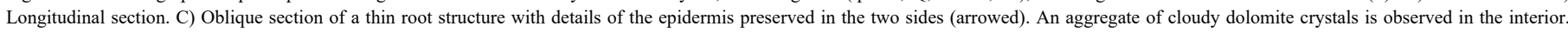

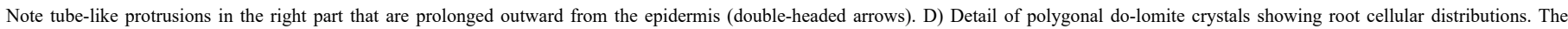
cloudy crystals are delineated by filaments and are surrounding some silicate grains. 

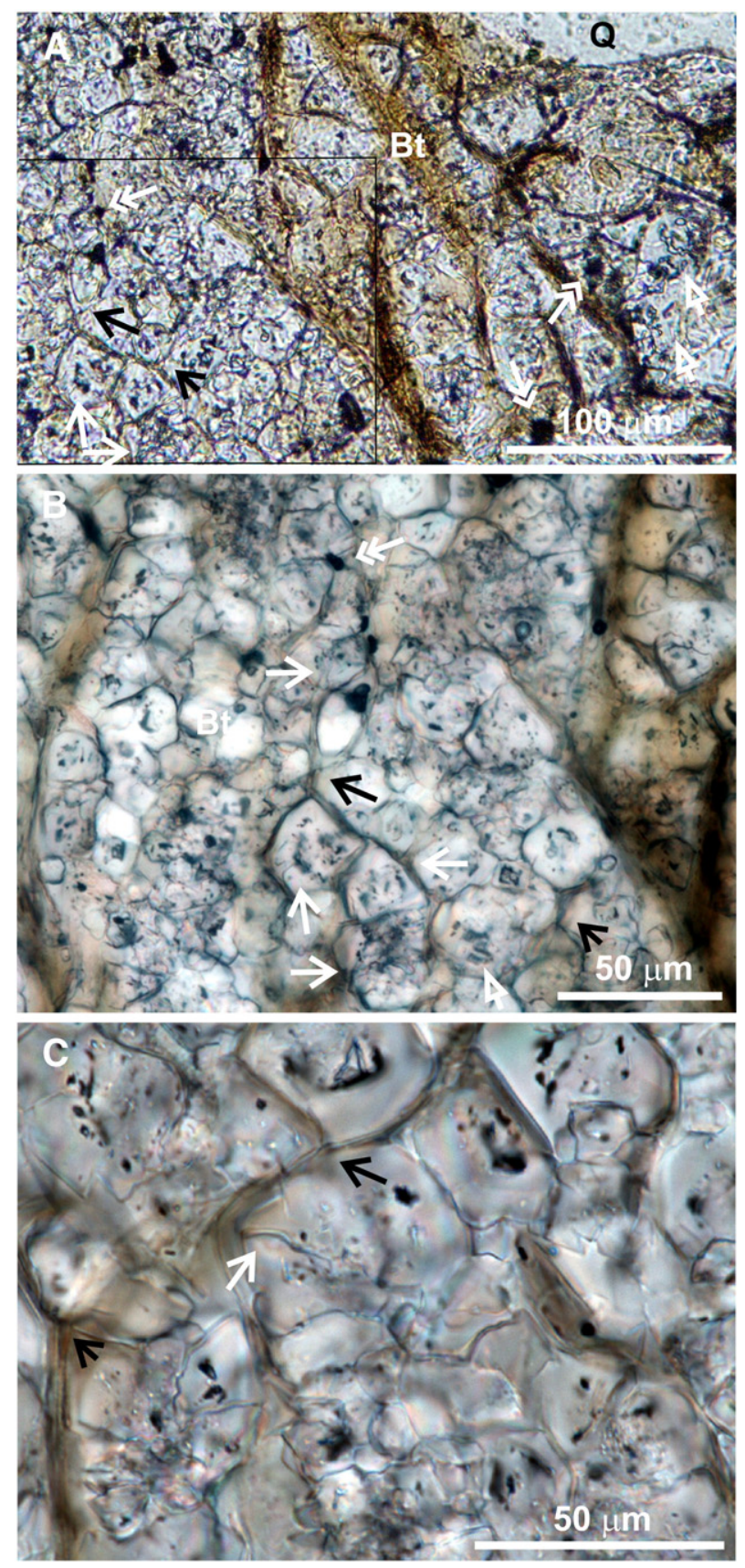

Fig. 5. Photomicrographs (plane-polarized light, A, and oil immersion, B and C) show-ing dolomite crystals associated with filaments and biotite flakes (Bt). A) Dolomite crystals are outlined by a network of long, branching filaments (black arrows) that may bifurcate within the crystals forming tree-like structures of thin filaments (white arrows) and include dark corpuscles (double-headed arrows) and coiled fila-ments (empty head arrow). B) Magnified view of area squared in A, See details of dichotomously-branched filaments (black arrow) and arbuscular structures, in some cases, extensively branched (white arrow). C) Magnified view of an arbuscule showing a large trunk, branched from an intercrystalline filament, and thin branches.

crystallized filaments (Fig. 8B,C). The network of filaments surrounds the dolomite crystals and bifurcates at varying angles. Some are seen to protrude into the carbonate forming filamentous to branched structures inside (Fig. 8B). Further the filament mesh seems to act as link between the biotite grains and the associated dolomite crystals (Fig. 8 C). Point EDS analyses of the etched biotite indicated that the phyllosilicate is enriched in silicon with respect to the other cations. Observations of root structures in freshly cut samples by SEM (Figs. 9 and 10), provided additional information on dolomite accumulation in rhizoliths. It is formed by complex interpenetrated crystalline aggregates
(Fig. 9). The aggregates show flattened to equidimensional rhombohedral or triangular crystals that have their faces depressed relative to their outer walls. Dolomicrosparite are associated to a meshwork of branching fila-ments with different sizes and morphologies. A first type is represented by tubular dichotomously-branched filaments, up to $3.0 \mu \mathrm{m}$ in $\mathrm{d}$ i a m e te $\mathrm{r}$, which are encrusted with micro-rod shaped crystals (Fig. 9A). A second type of smooth and thin filaments form densely intertwining spiral coils up to 25 $\mu \mathrm{m}$ indiameter( Fig. 9B). These are linked to clusters of branched tree-like filament of up to $10 \mu \mathrm{m}$ long, acicular crystals. In addition, the dolomite crystals are covered by abundant micro-rods (Fig. 9C).

Areas surrounding the crystalline aggregates of dolomite in rhizo-liths consist of a tangled interwoven network of tubules and branch-ing filaments that exhibit significant differences in size and shape (Fig. 10). Up-to-5 $\mu \mathrm{m}$ in diameter tubular filaments exhibit a Y-shaped branching pattern and are encrusted either with micro-rod crystals or with an array of acicular crystals (Fig. 10A). The tubes are interwoven with thin and repeatedly branched bushlike fila-ments (Fig. 10B). The silicate grains present in the closeness are enveloped and corroded by the filaments regardless of their mineral-ogy (Fig. 10B). The tubular filaments can be attached to carbonate globules up-to- $60 \mu \mathrm{m}$ in diameter, which are encrusted with micro-rod crystals (Fig. 10C). EDS point analyses indicated that the compo-sition of the variety of crystals associated to the filaments and the globule is calcite with low amounts of magnesium (Fig. $11)$.

\section{Interpretation and discussion}

Occurrences of crystalline mosaics in the same range of sizes, shapes, and arrangement have been elsewhere described in rhizocretion by Goldstein (1988); Sanz-Montero (1996) and Alonso-Zarza et al.(1998). The latter interpreted that the microsparitic mosaics formed through the calcification of root cells and pointed out that the structure of these forms is quite coincident with Microcodium (b) of Esteban (1972). This interpretation is reinforced with our additional observa-tions on the crystalline aggregates, especially those concerning the preservation of lignified sections of roots, likely the outermost part, and the depressed faces of the crystals that are similar to modern calcified cells illustrated, for example, by Jaillard (1987), Jaillard et al.(1991), Herrero (1991) and Kosir (2004). Both the single layer patterns of the crystals and the better crystallized faces at the root-soil (biotite) interface suggest that the carbonate precipitation took place preferen-tially in the cortical cells of the roots as commonly described in ancient carbonate soils (Klappa, 1978; Alonso-Zarza et al., 1998; Kosir, 2004; Zhou and Chafetz, 2009). However, the presence of a network of fila-ments delimiting the dolomicrosparite crystals that often has been ob-served to engulf and bifurcate in the carbonate to form filament coils and bush-like forms indicates that the process of carbonatation did not merely take place on uniform cell-roots. In fact, many of the variety of associated features have been extensively discussed in literature and in many cases have been attributed to rhizosphere organisms.

Carbonatic branched filaments between 1-4 $\mu \mathrm{m}$ in diameter are often found in carbonate paleosols and are interpreted as fungal hy-phae (Klappa, 1979). They may occur as isolated hypha but more commonly are clusters of intertwined filaments (mycelium). Fungi induce the precipitation of crystal as $\mathrm{Ca}$ and/or $\mathrm{Mg}$ oxalates and car-bonates that rapidly transform into more stable mineralogies (Gadd, 1999; Glowa et al., 2003; Kolo and Claeys, 2005; Verrecchia et al., 2006). Acicular or needle-fiber crystals are also an abundant compo-nent of carbonate paleosols (Wright, 2007) and its formation is accepted to take place by lysis of fungal sheaths (Phillips and Self, 1987; Verrecchia and Verrecchia, 1994; Cailleau et al., 2009; Millière et al., 2011). Micro-rod shaped crystals as those found associated to the dolomicrosparite aggregates (Fig. 9) could originate from fungal wall decay as demonstrated by Bindschedler et al. (2010). Along the same terms, Duckkett et al. (2006) reported the precipitation of acic-ular crystals, likely oxalates, in collapsed vesicles produced by 

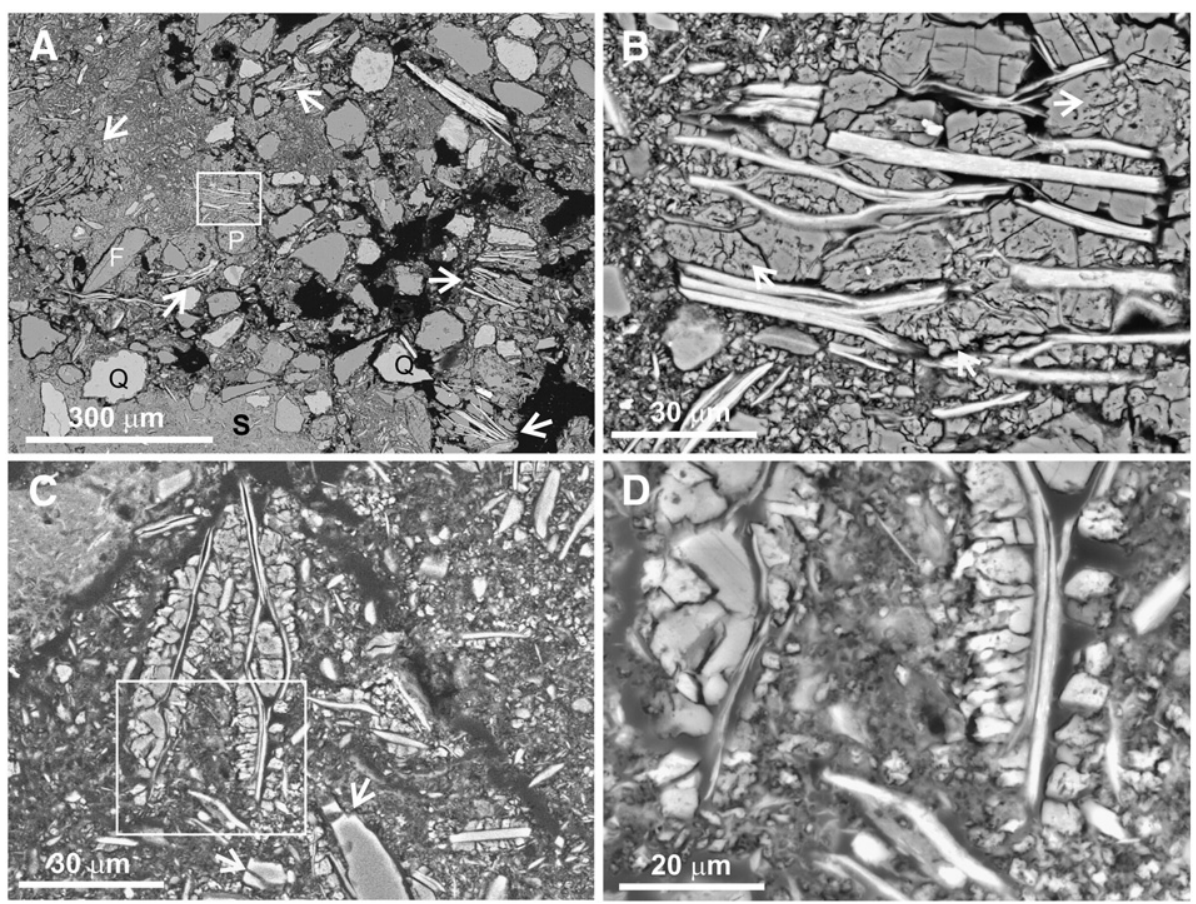

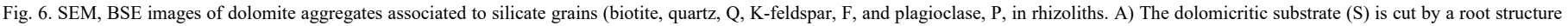

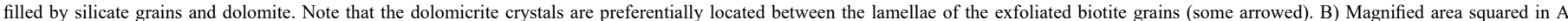

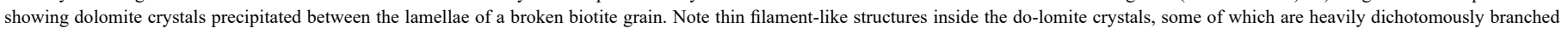

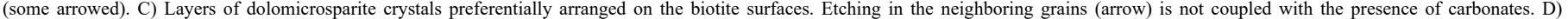

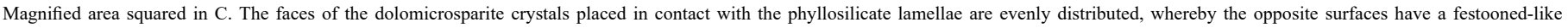
appearance. Contorted micrite crystals are interspersed in the surrounding matrix.

endomycorrhizal fungi within cortical root cells. As typically happens in endomycorrhizal associations and depicted in Fig. 12 (Moore et al., 2010), those globular vesicles are in connection with hyphal coils producing highly branched structures (known as an arbuscule) with-in the cells. Arbuscules consist of a basal trunk and repeatedly branched bush-like tuft. The fungal hyphae do not penetrate the inte-rior of the cell but invaginate the cell membrane. Endomycorrhizae, also called Arbuscular Mycorrhizae (AM), develop links between root cells and the mycelium network in the surrounding soil by means of specialized hyphae that penetrate into the root through the root hairs. Externally to the host, the fungal hyphae produce very large spores. The extraradical mycelium consists of two distinct types of hyphae, the runner hyphae and the absorbing hyphae (Friese and Allen, 1991). The runner hyphae are thicker and grow through the soil in search of roots. The hyphae that penetrate roots

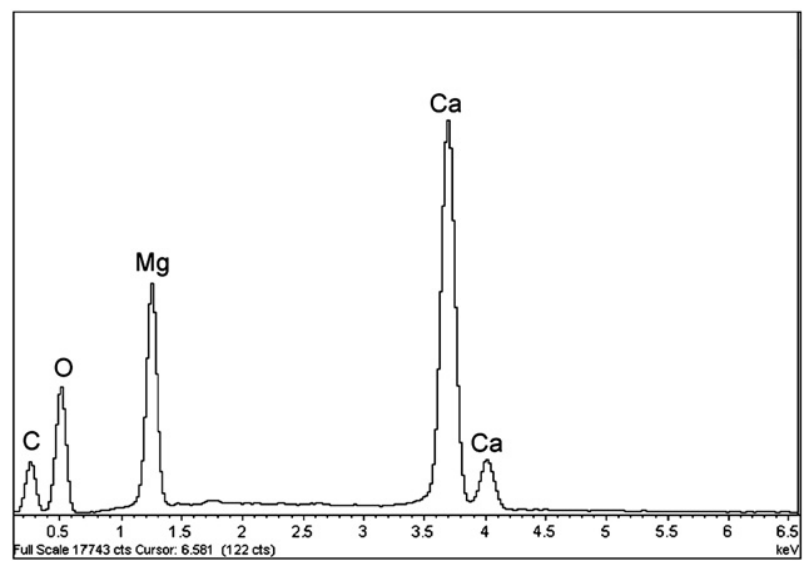

Fig. 7. EDS spectrum of dolomite microsparite associated to biotite. are initiated from runner hyphae. The absorbing hyphae also develop from the runner hyphae and form a network of thinner hyphae extending into the soil.

Both the external and the internal parts of the endomycorrhizae are quite well preserved and recognizable in the described Miocene rhizo-liths. So that, the extraradical mycelium network outspread in the sur-rounding soil with its typical large spores (globules) and the two characteristic types of hyphae (filaments), is found fossilized in calcite in the Miocene soils (Fig. 10). Similarly, the pattern and the variety of filaments preserved within the dolomite aggregates are analogous to the inner part of the modern mycelium developed in the cortical cells of the roots. Filament coils and tufts of fine branched hyphae forming arbuscule-like morphologies shown in Fig. 9B are morphologically iden-tical to those of living arbuscular mycorrhizae profusely illustrated in literature, for example, by Duckkett et al. (2006). Considering the distri-bution and morphology of black corpuscles observed under petrographic microscope (Fig. 5A), they may be tentatively attributed to the vesicles of endomycorrhizae, but attempts to identify them by SEM mi-croscopy have failed.

Thereby, a number of morphological and structural evidences, suggests that the dolomite aggregates and associated features formed in root bearing endomycorrhiza in the Miocene paleosols. Similar in-terpretation was given by Klappa (1978) for calcified structures, des-ignated as Microcodium, that were formed in recent Mediterranean caliche (calcrete). Later publications on root calcitization have hardly ever supported this interpretation, although Remy et al. (1994) also described vesicular arbuscular mycorrhizae in silicified plants and established that this type of symbiosis dates from the Early-Devonian.

Arbuscular mycorrhizal associations form intracellularly in the vast majority of herbaceous plants (Hodge, 2000). This is coherent with sedimentological and paleontological analyses for the Aragonian deposits of the Madrid Basin, indicating the proliferation of grami-neae prairies and xerophitic shrubs in the mudflats fringing the 

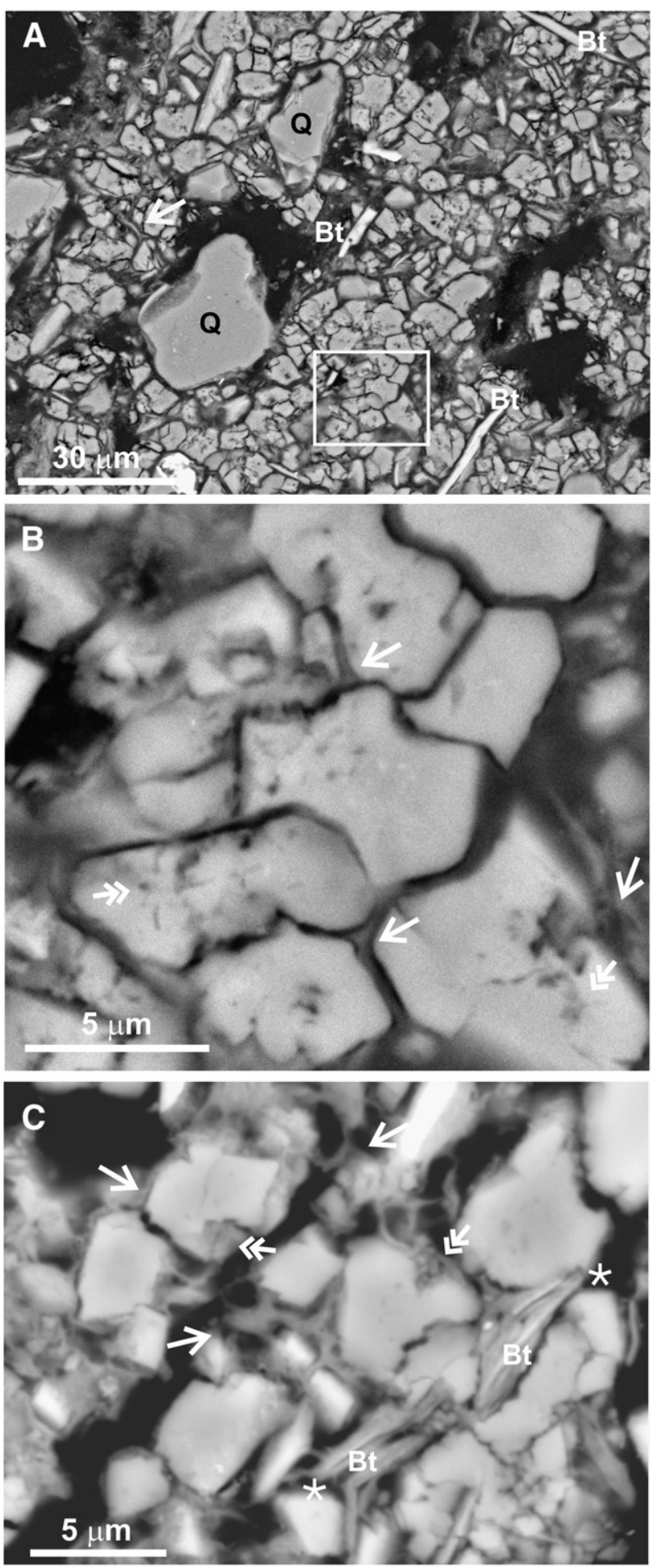

Fig. 8. SEM, BSE images of multilayered array of dolomicrosparite surrounding quartz (Q) and biotite grains $(\mathrm{Bt})$. A) General view of isodiametric dolomite crystals with cellular ar-chitecture. B) Magnified view of squared area en A. The inter-crystalline spaces of dolo-mite crystals with concave and convex surfaces are delimited by organic or poorly crystallized branched filaments (arrows). Coiled to branched stellate-shaped pores are recognizable inside the crystals (doubleheaded arrow). C) A network or thin organic fil-aments are attached to a biotite grain and to the dolomite crystals (arrows). Some are ob-served to invaginate inside the carbonate (double-headed arrow) and other filaments act as link between the carbonate and the silicate grains (asterisks).

shallow lakes (Rodríguez-Aranda and Calvo, 1998; Fernández Marrón et al., 2002).

Mycorrhizae are mutualistic, symbiotic associations. A number of experimental and field studies have shown the ability of mycorrhizal
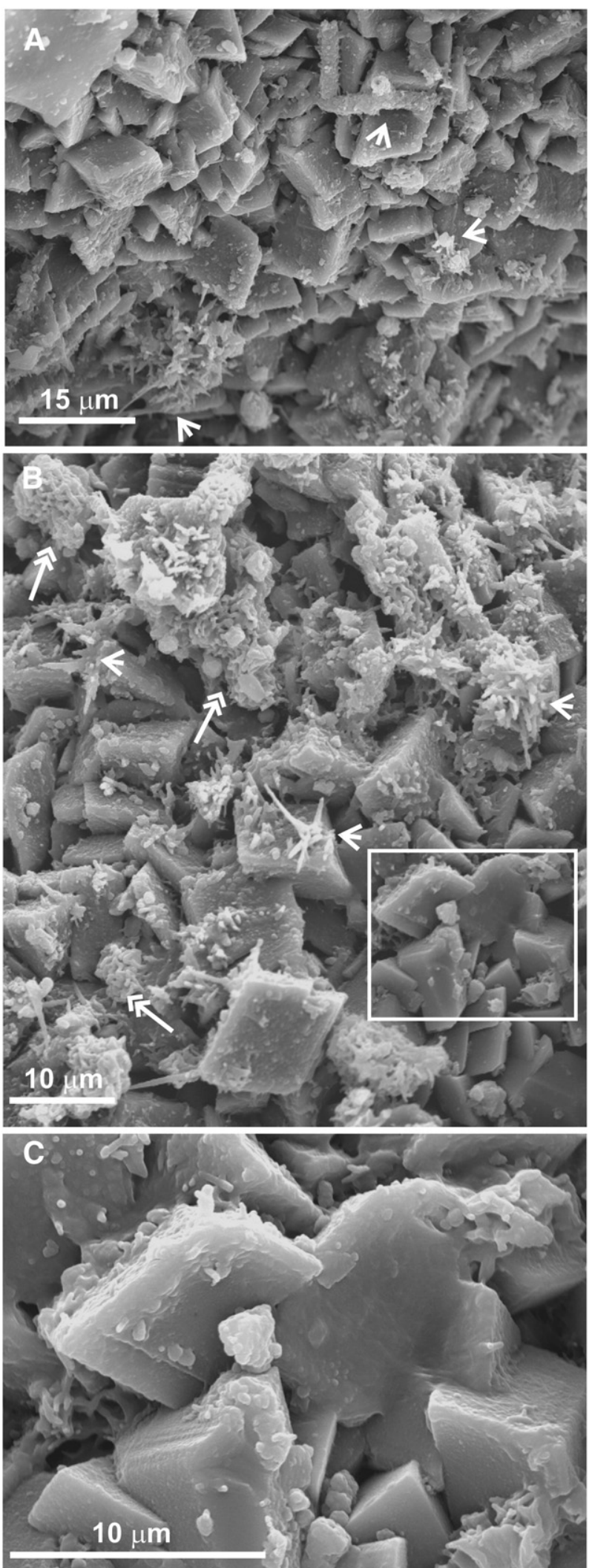

Fig. 9. SEM images of freshly cut sample of dolomite aggregates. A) Subidiomorph rhombohedral crystals occur associated to a meshwork of branching filaments with dif-ferent sizes of diameter (some arrowed). Note tubular dichotomously-branched fila-ments in the upper part. B) Clusters of short branched tree-like filament (arrow) and filament coils (double-headed arrows) coexist within the dolomite aggregates. C) Mag-nified view of squared area in B. Coiled filaments and micro-rods cover the interpene-trate dolomite crystals. Note concave faces in the crystals. 

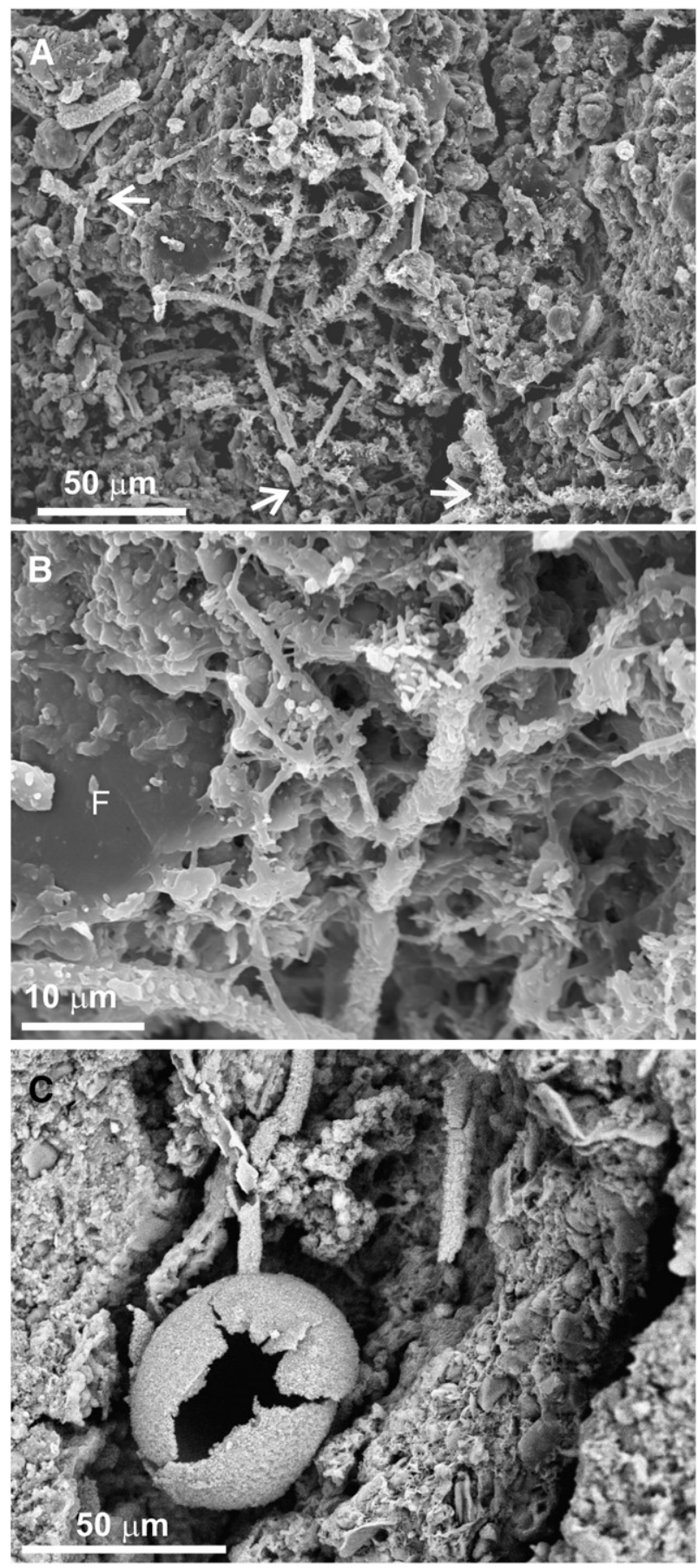

Fig. 10. SEM images of freshly cut sample of interwoven network of tubules and branching, thread-like filaments. A) Tubular filaments, up to $5 \mu \mathrm{m}$ in diameter, display a Y-shaped dichotomous branching pattern (arrows) and are encrusted with different shaped carbonate crystals. B) Magnified view of tubular filaments interwoven with thin and repeatedly branched bush-like filaments that corrode a K-feldspar grain (F). C) Tubular filament connected to a calcitic globule.

fungi to dissolve minerals in the process of extracting $\mathrm{P}, \mathrm{K}, \mathrm{Ca}, \mathrm{Mg}$ and $\mathrm{Fe}$ from soil minerals under nutrient limitations. Plants function both as a source of carbohydrate for the fungus and as a sink for cations weathered by the fungus. Our data concerning the attachment of extraradical fungal filaments and corrosion of detrital grains (Fig. 10) and the preferential formation of endomychorriza structures in association with deeply weathered biotite grains (Fig. 6) give arguments for the ability of fungi to extract beneficial nutrients from silicates in these paleosols. The biotite should have provided the greatest nutritional interest for the plants as evidenced by the direct attachment of their roots to this

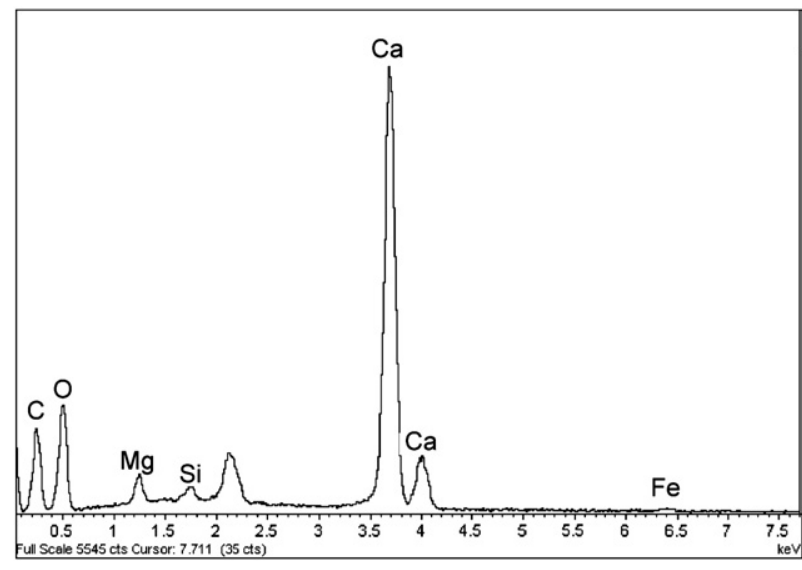

Fig. 11. Typical EDS spectrum of calcite crystals incrusting the filaments-forming network

mineral. Modern mycorrhizal fungi link root cells to soil particles (Ingham et al., 2000). The mineral grains are bound to a root by hyphae and the polysaccharides secreted by the plant and the fungus.

Although the mediated precipitation of dolomite by fungi has been reported to take place in building stones (Rodríguez-Navarro et al., 1997; Kolo et al., 2007; Jain et al., 2009), the precise mechanisms in-volved in the precipitation of dolomite in the rhizosphere remain elu-sive. It is also intriguing the close and pervasive association of weathered biotite grains with Mg-bearing carbonates in Miocene lacus-trine sedimentary successions, as documented by Sanz-Montero et al.(2009) and Sanz-Montero and Rodríguez-Aranda (2009, 2011).

The links between biologically induced mineral weathering and biogeochemical cycling in soils can be documented from the fossil record. Given the abundance of carbonatic paleosols in the geologic record, its study with this innovative approach may have important applications for understanding the long-term influence of the rhizosphere organ-isms on the precipitation of carbonates and the weathering of silicates.

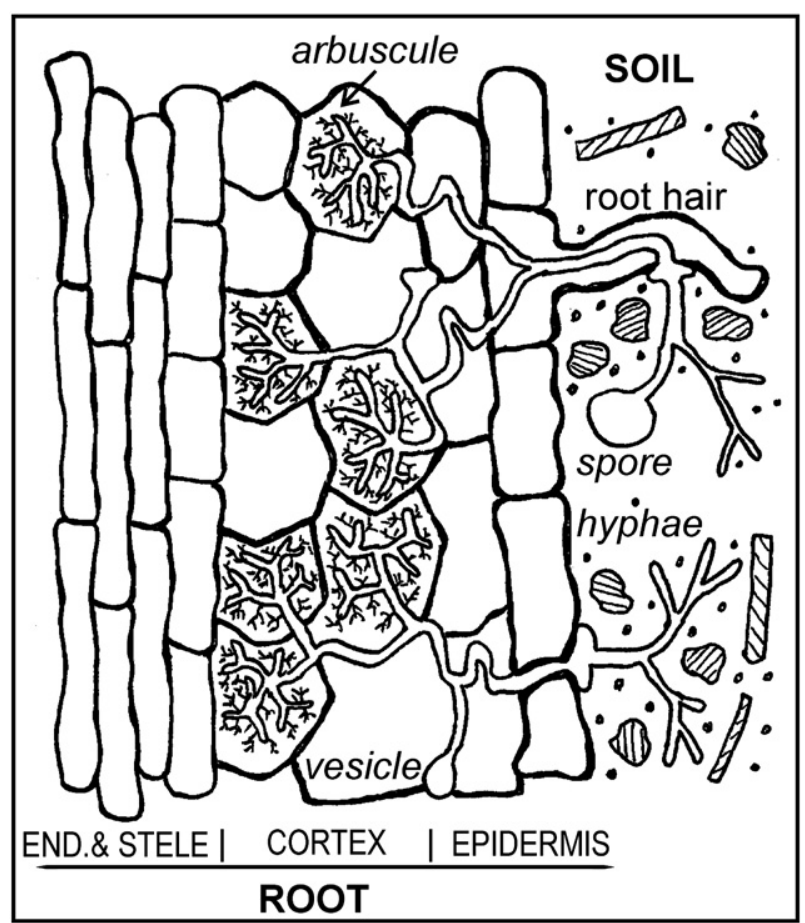

Fig. 12. Diagrammatic representation of the main cellular features of the arbuscular endomycorrhiza (modified from Moore et al., 2010). 


\section{Conclusions}

The lower part of the Intermediate Miocene Unit in the southwestern part of the Madrid Basin consists of siliciclastic and dolomitic rocks that were deposited in an alluvial fan-lake complex. In stability periods with low sedimentation rates and prevailing semi-arid conditions, the marginal lacustrine deposits may have been covered by herbaceous plants and xerophitic shrubs which would allow the formation of carbonatic soils.

Plants-forming carbonatic paleosols were intracellularly colonized by arbuscular mycorrhizae (or endomycorrhizae) whose remains and products are well preserved. Their remains, fossilized in carbonate, consist of two linked parts. The extraradicular part is represented by a calcitic mycelium comprising spores and two types of hyphae that are seen to attach and to etch mineral grains in the soil. The inner part is made of a network of branched filaments, arbuscules and likely vesicles that are mixed with the cortical root cells of the plants fossilized as dolomicrosparite aggregates.

It is suggested that biotite weathering was a process induced by mycorrhizae to acquire nutrients. The mechanisms that produce the mineral dissolution were likely involved in the precipitation of carbonates.

\section{Acknowledgment}

Our research is supported by projects 910404 (Programa de Grupos de Investigación Santander-UCM) and CGL2011-26781 (MICNN). We pay our sincere thanks to the department of microbiology 3 (UCM) for providing a high magnification microscope and to the Dr. L. Arregui for her kind assistance. The authors would also like to thank an anonymous reviewer for helpful comments and suggestions.

\section{References}

Alonso-Zarza, A.M., 2003. Palaeoenvironmental significance of palustrine carbonates and calcretes in the geological record. Earth-Science Reviews 60, 261-298. Alonso-Zarza,

A.M., Wright, V.P., 2010. Calcretes. In: Alonso-Zarza, A.M., Tanner, L.H.

(Eds.), Developments in Sedimentology. : Carbonates in Continental Settings, Vol. 61. Elsevier, The Netherlands, pp. 225-267. 2010.

Alonso-Zarza, A.M., Sanz, M.E., Calvo, J.P., Estévez, P., 1998. Calcified root cells in Miocene pedogenic carbonates of the Madrid Basin: evidence for the origin of Microcodium b. Sedimentary Geology 116, 81-97.

April, R., Keller, D., 1990. Mineralogy of the rhizosphere in forest soils of the eastern United States. Biogeochemistry 9, 1-18.

Balogh-Brunstad, Z., Kelly, C.K., Dickinson, T., 2008. Biotite Weathering and Nutrient Uptake by Ectomyccorhiza Fungus Suillus tomentosus in Liquid-Culture Experiments. Geochimica et Cosmochimica Acta 72, 2601-2618.

Berner, R.A., 1992. Weathering, plants, and the long-term carbon cycle. Geochimica et Cosmochimica Acta 56, 3225-3231.

Bindschedler, S., Millière, L., Cailleau, G., Job, D., Verrecchia, E.P., 2010. Calcitic nanofibers in soils and caves. a putative fungal contribution to carbonatogenesis. Journal Geological Society of London, Special Publication 336, 225-238.

Brasier, A.T., 2011. Searching for travertines, calcretes and speleothems in deep time: Processes, appearances, predictions and the impact of plants. Earth-Science Review 104 213-239.

Cailleau, G., Verrecchia, E.P., Braissant, O., Emmanuel, L., 2009. The biogenic origin of needle fibre calcite. Sedimentology 56, 1858-1875.

Calvaruso, C., Turpault, M.P., Frey-Klett, P., 2006. Root-associated bacteria contribute to mineral weathering and to mineral nutrition in trees: a budgeting analysis. Applied and Environmental Microbiology 72, 1258-1266.

Calvo, J.P., Daams, R., Morales, J., López Martínez, N., Agustí, J., Anadón, P., Armenteros, I., Cabrera, L., Civis, J., Corrochano, A., Díaz-Molina, M., Elizaga, E., Hoyos, M., MartínSuarez, E., Martínez, J., Moissenet, E., Muñoz, A., Pérez-García, A., Pérez-González, A., Portero, J.M., Robles, F., Santisteban, C., Torres, T., van der Meulen, A.J., Vera, J.A., Mein, P., 1993. Up-to-date Spanish continental Neogene synthesis and paleoclimatic interpretation. Revista de la Sociedad Geológica de España 6, 29-40.

Calvo, J.P., Alonso-Zarza, A.M., García del Cura, M.A., Ordóñez, S., Rodríguez-Aranda, J.P., Sanz-Montero, M.E., 1996. Sedimentary evolution of lake systems through Miocene, Madrid Basin. Paleoclimatic and Paleohydrological constraints. In: Friend, P., Dabrio, C.(Eds.), Tertiary Basins of Spain. Cambridge University Press, Cambridge, pp. 264-269.

Christophe, C., Turpault, M.P., Freyklett, P., 2006. Root associated bacteria contribute to mineral weathering and to mineral nutrition in trees and budgeting analysis. Applied and Environmental Microbiology 72, 1258-1266.

Duckkett, J.G., Carafa, A., Ligrone, R., 2006. A highly differentiated glomeromycotean association with the mucilage-secreting, primitive antipodean liverwort Treubia (Treubiaceae): clues to the origins of mycorrhizas. American Journal of Botany 93, 797-813.
Esteban, M., 1972. Una nueva forma de prismas de Microcodium elegans (Gluek 1912) y su relación con el caliche del Eoceno Inferior, Marmella, provincia de Tarragona (España): Inst. Investigaciónes Geológicas: Revista Univ. Barcelona, vol. 27, pp. $65-81$.

Fernández Marrón, M.T., Fonollá, J.F., Jiménez Rodrígo, J.C., 2002. Primeros datos paleobotánicos y palinológicos de una flora miocénica procedente de la Unidad Intermedia en el sector central de la Cuenca de Madrid. Geogaceta 31, 177-180.

Friese, C.F., Allen, M.F., 1991. The spread of VA mycorrhizal hyphae in the soil: inoculum types and external hyphal architecture. Mycologia 83, 409-418.

Gadd, G.M., 1999. Fungal production of citric and oxalic acid: importance in metal speciation, physiology and biogeochemical processes. Advances in Microbial Physiology 41, 47-92.

Glowa, K.R., Arocena, J.M., Massicotte, H.B., 2003. Extraction of potassium and/or magnesium from selected minerals by Piloderma. Geomicrobiology Journal 20, 99-111.

Goldstein, R.H., 1988. Paleosols of Late Pennsylvanian cyclic strata, New Mexico. Sedimentology $35,777-803$

Goudie, A.S., 1983. Calcrete. In: Goudie, A.S., Pye, K. (Eds.), Chemical Sediments and Geomorphology. Academic Press, London, pp. 93-131.

Herrero, J., 1991. Morfología y génesis de suelos sobre yesos. Monografías INIA, nº 77. $447 \mathrm{pp}$.

Hinsinger, Ph., Bengough, A.G., Vetterlein, D., 2006. Rhizosphere: biophysics, biogeochemistry and ecological relevance. Plant and Soil 321, 117-152.

Hodge, A., 2000. Microbial ecology of the arbuscular mycorrhiza. FEMS Microbiology Ecology 32, 91-96.

Ingham, E., Moldenke, A.R., Edwards, C.A., 2000. Soil biology primer. Soil and Water Conservation Society (U.S.), United States. Natural Resources Conservation Service, Ankeny, Iowa. $48 \mathrm{pp}$.

Jaillard, B., 1987. Les structures rhizomorphes calcaires: modele de reorganisation des mineraux du sol par les raciness. Publ. INRA, Montpellier, France. 228 pp.

Jaillard, B., Guyon, A., Maurin, A.F., 1991. Structures and composition of calcified roots, and their identification in calcareous soils. Geoderma 50, 197-210.

Jain, A., Bhadauria, S., Kumar, V., Chauhan, R.S., 2009. Biodeterioration of sandstones under the influence of different humidity levels in laboratory conditions. Building and Environment 44, 1276-1284.

Klappa, C.F., 1978. Biolithogenesis of microcodium: elucidation. Sedimentology 25, 489-522.

Klappa, C.F., 1979. Calcified filaments in Quaternary calcretes: organo-mineral interactions in the subaerial vadose environment. Journal of Sedimentary Research 49, 955-968.

Klappa, C.F., 1980. Rhizoliths in terrestrial carbonates: classification, recognition, genesis and significance. Sedimentology 27, 613-629.

Kolo, K., Claeys, Ph., 2005. In vitro formation of Ca-oxalates and the mineral glushinskite by fungal interaction with carbonate substrates and seawater. Biogeosciences 2, 277-293.

Kolo, K., Keppens, E., Preat, A., Claeys, Ph., 2007. Experimental observations on fungal diagenesis of carbnate substrates. Journal of Geophysical Research 112, 1-20.

Kosir, A., 2004. Microcodium revisited: root calcification products of terrestrial plants on carbonate-rich substrates. Journal of Sedimentary Research 74, 845-857. Manning,

D.A.C., 2008. Biological enhancement of soil carbonate precipitation: passive removal of atmospheric $\mathrm{CO}_{2}$. Mineralogical Magazine 72, 639-649.

Millière, L., Hasinger, O., Bindschedler, S., Cailleau, G., Spangenberg, J.E., Verrecchia, E.P., 2011. Stable carbon and oxygen isotope signature of pedogenic needle fibre calcite: further insight into its origin and relationship with soil conditions. Geoderma 161, 74-87. Moore, D.,

Robson, G.D., Trinci, A.P.J., 2010. (Online) http://sbli.ls.manchester.ac.uk/ fungi/21st_Century_Guidebook_to_Fungi/Ch13_10.htm.

Phillips, S.E., Self, P.G., 1987. Morphology, crystallography and origin of needle-fibre calcite in Quaternary pedogenic carbonates of South Australia. Australian Journal Soil Research 25, 429-444.

Remy, W., Taylor, T.N., Hass, H., Kerp, H., 1994. Four hundred-million-year-old vesicular arbuscular mycorrhizae. Proceedings of the National Academy of Sciences of the United States of America 91, 11841-11843.

Rodríguez-Aranda, J.P., Calvo, J.P., 1998. Trace fossils and rhizoliths as a tool for sedimentological and paleoenvironmental analysis of ancient evaporite successions. Palaeogeography, Palaeoclimatology, Palaeoecology 140, 383-399.

Rodríguez-Aranda, J.P., Calvo, J.P., Sanz-Montero, M.E., 2002. Lower Miocene gypsum palaeokarst in the Madrid Basin (central Spain): dissolution, diagenesis, morpho-logical relics and karst end-products. Sedimentology 49, 1385-1400.

Rodríguez-Navarro, C., Sebastián, E., Rodríguez-Gallego, M., 1997. An urban model for dolomite precipitation: authigenic dolomite on weathered building stones. Sedimentary Geology 109, 1-11.

Sanz, M.E., Alonso-Zarza, A.M., Calvo, J.P., 1994. Carbonate pond deposits related to semi-arid alluvial systems: examples from the Tertiary Madrid Basin, Spain. Sedimentology 42, 437-452.

Sanz-Montero, M.E., 1996. Sedimentología de las formaciones neogénas del Sur de la Cuenca de Madrid. CEDEX: Monografías, vol. 52. 245 pp.

Sanz-Montero, M.E., Rodríguez-Aranda, J.P., 2009. Silicate bioweathering and biomineralization in lacustrine microbialites: ancient analogues from the Miocene Duero Basin, Spain. Geological Magazine 146, 527-539.

Sanz-Montero, M.E., Rodríguez-Aranda, J.P., 2011. Magnesite formation by microbial activity: evidence from a Miocene hypersaline lake. Sedimentary Geology. doi:10.1016/j.sedgeo.2011.08.004 (Electronic publication ahead of print).

Sanz-Montero, M.E., Wright, V.P., 1994. Modelo alternativo para el desarrollo de calcre-tas: Un ejemplo del Plio-Cuaternario de la Cuenca de Madrid. Geogaceta 16, 106-109. Sanz-Montero, M.E., Rodríguez-Aranda, J.P., Pérez-Soba, C., 2009. Microbial weathering of Fe-rich phyllosilicates and formation of pyrite in the dolomite precipitating environ-ment of a Miocene lacustrine system. European Journal of Mineralogy 21, 163-175. 
Stucki, J.W., Bailey, G.W., Gan, H., 1996. Oxidation-reduction mechanisms in ironbearing phyllosilicates. Applied Clay Science 10, 417-430.

Uroz, S., Calvaruso, C., Turpault, M.-P., Frey-Klett, P., 2009. Mineral weathering by bacteria: ecology, actors and mechanisms. Trends in Microbiology 17, 378-387. Verrecchia,

E.P., Verrecchia, K.E., 1994. Needle-fiber calcite: a critical review and a proposed classification. Journal of Sedimentary Research A64, 650-664.

Verrecchia, E.P., Braissant, O., Cailleau, G., 2006. The oxalate-carbonate pathway in soil carbon storage: the role of fungi and oxalotrophic bacteria. In: Gadd, G.M. (Ed.), Fungi in Biogeochemical Cycles. Cambridge University Press, Cambridge, pp. 298-310.
Wright, V.P., 2007. Calcretes. In: Nash, D., McLaren, S. (Eds.), Geochemical Sediments and Landscapes. Wiley-Blackwell, Oxford, UK, pp. 10-45.

Wright, V.P., Tucker, M.E., 1991. Calcretes. An introduction. In: Wright, V.P., Tucker, M.E. (Eds.), Calcretes. : IAS Reprint Series, vol. 2. Blackwell, Oxford, pp. 1-22. Zhou, J., Chafetz, H.S., 2009. Biogenic caliches in Texas: the role of organisms and effect of climate. Sedimentary Geology 222, 207-225. 